\title{
Application of Chitosan and Its Derivative Polymers in Clinical Medicine and Agriculture
}

\author{
Meng Zhang ${ }^{1,2,+}\left(\mathbb{D}\right.$, Fengshi Zhang ${ }^{1,2,+} \oplus, \mathrm{Ci} \mathrm{Li}^{1,2}$, Heng An ${ }^{3}$, Teng Wan ${ }^{1,2}$ and Peixun Zhang ${ }^{1,2,4, *}$ \\ 1 Department of Orthopedics and Trauma, Peking University People's Hospital, Beijing 100044, China; \\ mengzh2008@bjmu.edu.cn (M.Z.); xmx066@pku.edu.cn (F.Z.); drlici@bjmu.edu.cn (C.L.); \\ tengwan.med@hotmail.com (T.W.) \\ 2 Key Laboratory of Trauma and Neural Regeneration, Peking University, Beijing 100044, China \\ 3 Beijing Key Laboratory for Bioengineering and Sensing Technology, Daxing Research Institute, School of \\ Chemistry \& Biological Engineering, University of Science \& Technology Beijing, Beijing 100083, China; \\ hengan@xs.ustb.edu.cn \\ 4 National Center for Trauma Medicine, Beijing 100044, China \\ * Correspondence: zhangpeixun@bjmu.edu.cn \\ + These authors contributed equally to this work.
}

check for updates

Citation: Zhang, M.; Zhang, F.; Li, C.; An, H.; Wan, T.; Zhang, P. Application of Chitosan and Its Derivative Polymers in Clinical Medicine and Agriculture. Polymers 2022, 14, 958. https://doi.org/ $10.3390 /$ polym 14050958

Academic Editors: André Ricardo

Fajardo, Ismael Bellettini and Luminita Marin

Received: 31 December 2021 Accepted: 17 February 2022 Published: 28 February 2022

Publisher's Note: MDPI stays neutral with regard to jurisdictional claims in published maps and institutional affiliations.

Copyright: (C) 2022 by the authors. Licensee MDPI, Basel, Switzerland. This article is an open access article distributed under the terms and conditions of the Creative Commons Attribution (CC BY) license (https:// creativecommons.org/licenses/by/ $4.0 /)$.

\begin{abstract}
Chitosan is a biodegradable natural polymer derived from the exoskeleton of crustaceans. Because of its biocompatibility and non-biotoxicity, chitosan is widely used in the fields of medicine and agriculture. With the latest technology and technological progress, different active functional groups can be connected by modification, surface modification, or other configurations with various physical, chemical, and biological properties. These changes can significantly expand the application range and efficacy of chitosan polymers. This paper reviews the different uses of chitosan, such as catheter bridging to repair nerve broken ends, making wound auxiliaries, as tissue engineering repair materials for bone or cartilage, or as carriers for a variety of drugs to expand the volume or slow-release and even show potential in the fight against COVID-19. In addition, it is also discussed that chitosan in agriculture can improve the growth of crops and can be used as antioxidant coating because its natural antibacterial properties are used alone or in conjunction with a variety of endophytic bacteria and metal ions. Generally speaking, chitosan is a kind of polymer material with excellent development prospects in medicine and agriculture.
\end{abstract}

Keywords: chitosan; chitosan derivative; biopolymers; biomedical; agriculture; delivery systems; wound dressing

\section{Introduction}

Chitosan is a degradable multifunctional biopolymer obtained by chemical or enzymatic deacetylation from crustacean exoskeleton, insect cuticle, and fungal mycelium, which is a D-glucosamine linked by a $\beta-1,4$ glycosidic bond [1,2] (Figure 1A,B). By modifying chitosan, chitosan derivatives with different properties are generated, which are widely used in many fields such as biomedicine, agriculture, wastewater treatment, and food preservation [3,4]. In recent years, chitosan and its derivatives have received considerable attention for applications in nerve injury repair, wound repair, and as drug delivery systems due to their excellent properties in antibacterial, biocompatibility, and biodegradation [5].

The agricultural sector is facing great challenges with the increase in population, decrease in arable land, and increase in plant diseases caused by pathogens. Plant pathogens produce harmful toxins that cause slow crop growth and reduced yields, which can cause significant economic losses. However, over-reliance on existing fungicides to solve this problem is bound to have an impact on ecological diversity and public health safety. Therefore, there is an urgent need to develop antimicrobial drugs with new targets. Chitosan and its derivatives have become a research hotspot in the fields of plant growth stimulants and 
biological antimicrobial insecticides because of their broad-spectrum resistance to bacteria and fungi, biodegradability, biocompatibility, and plant growth-stimulating effects.

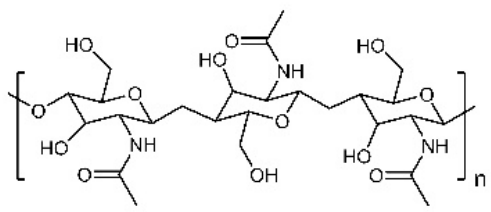

Chitin

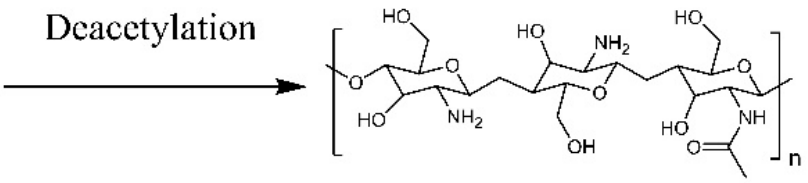

Chitosan

Figure 1. Preparation of chitosan by deacetylation. Chitosan (B) is formed by deacetylation of chitin (A).

\section{Physicochemical Properties of Chitosan}

Chitosan has excellent biological properties such as biodegradability, biocompatibility, antibacterial, anti-tumor, hemostatic and antioxidant properties [6,7]. The biological properties of chitosan are closely related to its physicochemical structure, which includes the degree of deacetylation, water content, and molecular weight [8]. Deacetylation refers to the process of removing the acetyl group from chitosan, and this process determines the content of free amine groups in chitosan. Studies have shown that chitosan has good solubility only when the degree of deacetylation is above $85 \%$. The enhanced chitosan uptake is mainly due to the interaction of positively charged chitosan with cell membranes, activation of chlorine-bicarbonate exchange channels, and reorganization of proteins associated with epithelial tight junctions, thus opening epithelial tight junctions $[9,10]$. Chitosan inhibits different species of microorganisms such as bacteria and fungi, and the mechanism is influenced by several factors, including the degree of deacetylation, $\mathrm{pH}$, divalent cations, and solvent type. Oligomeric chitosan penetrates cell membranes more easily than high molecular weight chitosan and inhibits bacterial growth by inhibiting RNA transcription [8].

\subsection{Chitosan Modification}

Chitosan is widely found in nature and contains the following three functional groups: $\mathrm{C} 2-\mathrm{NH} 2, \mathrm{C} 3-\mathrm{OH}$, and $\mathrm{C} 6-\mathrm{OH}$ as in Figure 1B. $\mathrm{C} 3-\mathrm{OH}$ has a large spatial site resistance and therefore is relatively difficult to modify. $\mathrm{C} 2-\mathrm{NH} 2$ is highly reactive for fine modifications and is the most common modifying group in chitosan [11]. In chitosan, although amino groups are more prone to nucleophilic reactions than hydroxyl groups, both can react non-selectively with electrophilic reagents such as acids, chlorides, and haloalkanes to functionalize them [12]. However, the low bioactivity and solubility of chitosan at physiological $\mathrm{pH}$ conditions due to its $\mathrm{pH}$ of about 6.5 certainly limits the application of chitosan. Therefore, reasonable modifications and modifications of chitosan are needed to obtain derivatives with increased activity and improved water solubility. Since chitosan contains a variety of functional groups, it can be functionalized in different ways such as phosphorylation, thiolation, and carboxylation (Table 1). 
Table 1. Modification of chitosan and its derivatives and their significant properties.

\begin{tabular}{|c|c|c|c|c|}
\hline Types & Functional Group & Common Derivatives & Applications & Reference \\
\hline $\begin{array}{l}\text { Thiolated chitosan } \\
\text { derivatives }\end{array}$ & the thiol groups & $\begin{array}{l}\text { chitosan-6-mercaptonicotinic acid; } \\
\text { chitosan-4-thiobutylamidine; }\end{array}$ & $\begin{array}{l}\text { Tissue-engineered scaffolds; } \\
\text { Drug delivery nanocarriers; } \\
\text { Wastewater treatment; } \\
\text { Antibacterial activity; }\end{array}$ & [13] \\
\hline $\begin{array}{l}\text { Phosphorylation of } \\
\text { chitosan derivatives }\end{array}$ & phosphate groups & N-methylene phosphonic chitosan & $\begin{array}{l}\text { Induced bone formation; } \\
\text { Increased solubility; } \\
\text { Fuel cell; }\end{array}$ & [14] \\
\hline $\begin{array}{c}\text { Crosslinked } \\
\text { chitosan derivatives }\end{array}$ & $\begin{array}{l}\text { cross-linking } \\
\text { bridges }\end{array}$ & $\begin{array}{l}\text { Ethylene diamine tetraacetic acid } \\
\text { chitosan polymer; } \\
\text { Chitosan-glutaraldehyde } \\
\text { cross-linked polymers; }\end{array}$ & $\begin{array}{l}\text { Drug delivery systems; } \\
\text { Biosorbents; }\end{array}$ & [15] \\
\hline $\begin{array}{l}\text { Carboxylic acid } \\
\text { chitosan derivatives }\end{array}$ & $\begin{array}{l}\text { Carboxymethyl } \\
\text { group }\end{array}$ & $\begin{array}{l}\text { N, O-carboxymethyl chitosan; } \\
\text { N, N-carboxymethyl chitosan; } \\
\text { Chitosan-methacrylate; }\end{array}$ & $\begin{array}{c}\text { Tissue engineering scaffold } \\
\text { materials; } \\
\text { food industry; } \\
\text { nanobiosensors }\end{array}$ & [16] \\
\hline $\begin{array}{l}\text { Cationic chitosan } \\
\text { derivatives }\end{array}$ & $\begin{array}{l}\text { quaternary } \\
\text { functional groups }\end{array}$ & $\begin{array}{c}\mathrm{N}-(2 \text {-hydroxy) } \\
\text { propyl-3-trimethylammonium } \\
\text { chitosan; } \\
\text { chitosan-(mono, di, } \\
\text { tri)chloroacetate; } \\
\text { chitosan-trifluoroacetate; }\end{array}$ & $\begin{array}{l}\text { Antibacterial activity; } \\
\text { Increased water solubility; } \\
\text { Antioxidant reagent; }\end{array}$ & [17] \\
\hline $\begin{array}{l}\text { Sulfated chitosan } \\
\text { derivatives }\end{array}$ & $-\mathrm{SO}_{4}{ }^{2-}$ groups & $\begin{array}{l}\text { 6-O-sulfated chitosan; } \\
\text { 2-N,6-O-sulfated chitosan; }\end{array}$ & $\begin{array}{l}\text { Tissue repair and regeneration; } \\
\text { anticoagulation; } \\
\text { antioxidant; } \\
\text { antiviral }\end{array}$ & [18] \\
\hline
\end{tabular}

\subsubsection{Phosphorylated Chitosan}

The good water solubility and metal chelating properties of phosphorylated chitosan and its derivatives make them widely used in tissue engineering, drug delivery carriers, tissue regeneration, and the food industry [19-21]. As in Figure 2, water-soluble phosphorylated chitosan was obtained by the reaction of phosphorus pentoxide and chitosan under low-temperature conditions using methane sulfonic acid as the catalyst (Figure 2A); phosphorylated chitosan with good antibacterial activity and ionic properties was prepared by graft copolymerization of chitosan monophosphate [22,23] (Figure 2B). Phosphorylated chitosan has a better welling index and ionic conductivity properties. The crystallinity was reduced compared to chitosan, but the tensile strength was not significantly changed. Renata et al. improved the osteogenic activity of chitosan-xanthan gum scaffolds by introducing phosphate groups to chitosan's amino and hydroxyl groups. In addition, signaling molecules, such as bone morphogenetic proteins and growth factors bound to the surface of phosphorylated chitosan, were able to induce directed differentiation of stem cells into osteoblasts [24]. Phosphorylated chitosan has a significant pro-value-added effect on osteoblasts, making it potentially valuable for a wide range of applications in bone tissue engineering. The solubility of chitosan-based hydrogels was significantly reduced at $\mathrm{pH}>6.5$. To solve this problem, the derivative N-methylene phosphonic acid chitosan (NMPC-GLU) was synthesized by cross-linking glutaraldehyde. The introduction of methylene phosphonic acid allows chitosan to improve solubility under $\mathrm{pH}$-neutral conditions without reducing film-forming properties. Excellent compressive strength, elastic modulus, and promotion of cell proliferation were observed in the hydrogels prepared in this way [25]. 


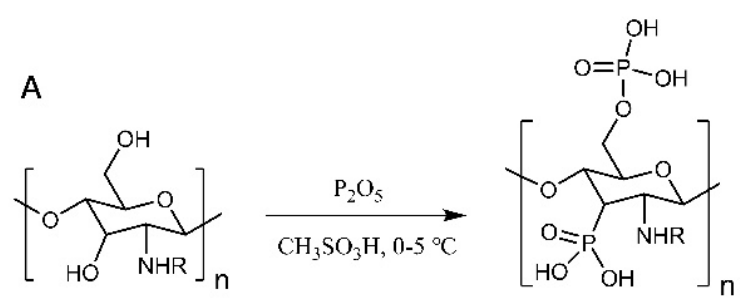

B

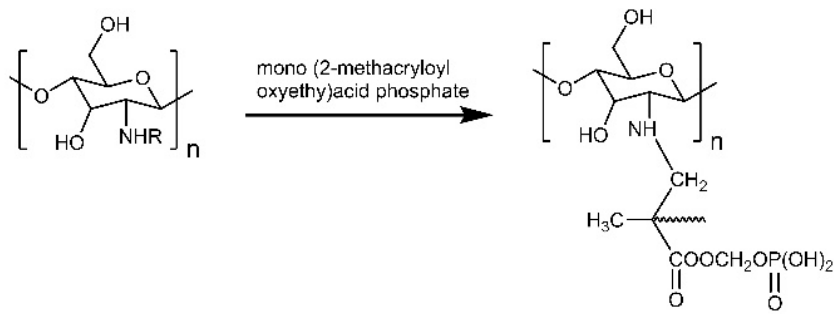

Figure 2. Phosphorylated chitosan. (A) Reaction of phosphorus pentoxide and chitosan to obtain highly substituted and water-soluble phosphorylated chitosan. (B) Preparation of phosphorylated chitosan by graft copolymerization of mono(2-methacryloyloxyethyl) phosphate chitosan.

\subsubsection{Thiolated Chitosan}

Thiol chitosan is prepared by the derivatization of the amino group of chitosan with a thiol-containing coupling reagent [26,27]. The amino group at the 2nd position of chitosan glucosamine is the primary site of thiol group immobilization. The thiol-containing solvent attaches to chitosan by forming an amide bond with the primary amino group of chitosan. Under the conditions of amide bond formation, the carboxyl group of thioglycolic acid and the ligand cysteine mediate the reaction with the amino group of chitosan through watersoluble carbodiimide. The concentration of thiolate anions reflecting the activity of the thiol groups is low at $\mathrm{pH}<5$ during the reaction, which limits the formation of disulfide bonds [3]. The modified chitosan exhibits excellent properties due to the covalent attachment of the thiol groups to the chitosan. Additionally, the lower $\mathrm{pH}$ of the surrounding medium reduces the thiol chitosan activity, which reduces the oxidation of the modified chitosan and leads to enhanced adhesion properties [28-30]. Thiochitosan interacts with cysteines in membrane receptors, such as epidermal growth factor, causing intracellular tyrosine kinase activation, which enhances membrane permeability [31]. In conclusion, thiochitosan has good adhesion ability, inhibitory effect on phosphorylated glycoproteins, and enhanced membrane permeability. Li et al. used thiochitosan as a coating material to modify stainless steel containing maleimido-containing tannic acid (TAMA) and found a 70\% reduction in adsorption to E. coli and a 90\% reduction in adhesion [32,33]. The thiosemicarbazone coating modification method is important in inhibiting bacterial adhesion and biofilm formation on susceptible materials.

\subsubsection{Ionic Chitosan}

Cationic derivatives of chitosan have important roles in bioadhesion, absorption enhancement, anti-inflammatory, antibacterial and anti-tumor applications. Chitosan modified with quaternary ammonium groups is one of the most common cationic chitosan derivatives. Quaternized chitosan with a permanent positive charge has increased antimicrobial activity and solubility compared to normal chitosan [34]. As illustrated in Figure 3, there are two main methods of chitosan quaternization: direct quaternization and indirect quaternization. One method of direct quaternization of chitosan amino acids is to treat chitosan with haloalkanes under alkaline conditions (Figure 3A). Another method is the reaction of chitosan with aldehydes first, further by sodium borohydride or reduction, and finally with haloalkanes to obtain quaternized chitosan $[35,36]$ (Figure 3B). As seen in 
Figure 4, the indirect quaternization method refers to introducing small molecules containing quaternary ammonium groups into chitosan, such as glycidyl trimethyl ammonium chloride, (5-bromopentyl) trimethyl ammonium bromide, etc. [37,38] (Figure 4A,B). Tan et al. introduced quaternary ammonium groups into the chitosan backbone via azidealkyne cycloaddition reactions to synthesize 1,2,3-triazole chitosan derivatives [39], which pointed the way to the antifungal and antioxidant properties of chitosan derivatives for a wide range of applications in biomedicine. Quaternized chitosan was prepared by dissolving chitosan in alkali and urea and then reacting it with 3-chloro-2-hydroxypropyl trimethylammonium chloride [40] (Figure 4C), which provides a simple and green solution to achieve chitosan functionalization.

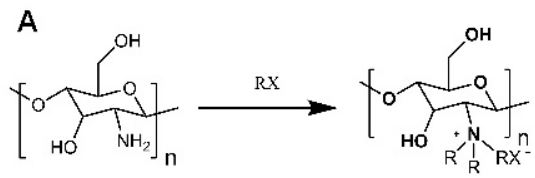

B

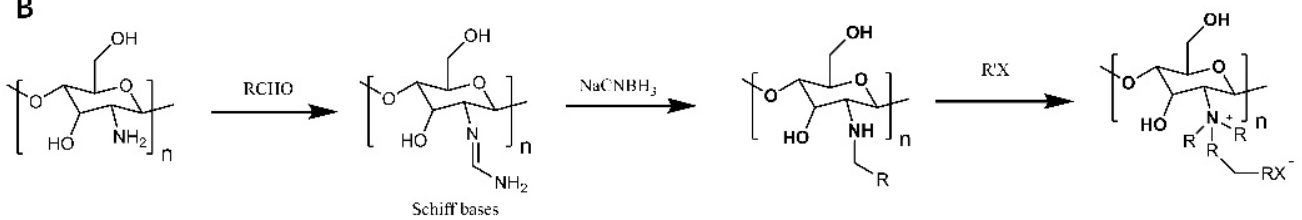

Figure 3. Direct quaternization of chitosan. (A) Processing of chitosan by haloalkanes under alkaline conditions. (B) Chitosan is first reacted with aldehyde, further reduced by sodium borohydride or sodium cyanoborohydride, and finally reacted with haloalkanes to obtain quaternized chitosan.

A

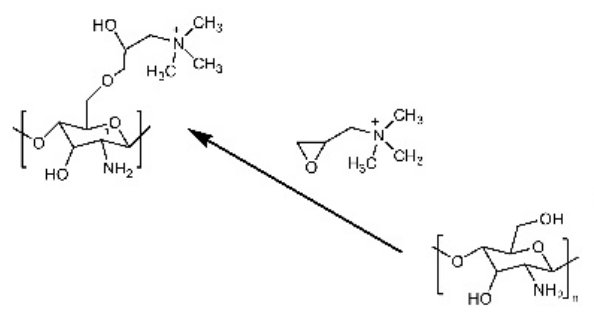

B

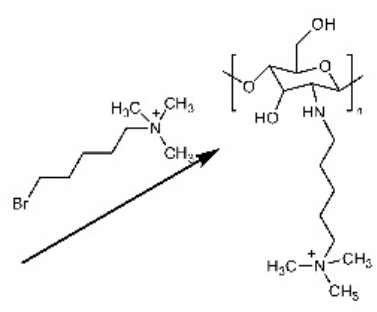

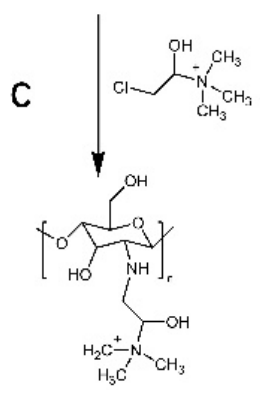

Figure 4. Indirect quaternization of chitosan. Introduction of small molecules containing quaternary ammonium groups into chitosan. (A) (5-bromopentyl)trimethylammonium bromide. (B) trimethylammonium chloride of glycidyl ester. (C) Preparation of quaternized chitosan by reaction of chitosan 3-chloro-2-hydroxypropyltrimethylammonium chloride.

\section{Chitosan in Biomedical Applications}

\subsection{Anti-Tumor Effects of Chitosan and Its Derivatives}

Cancer is one of the major diseases that threatens human health today, and according to statistics, it is responsible for about one-sixth of deaths worldwide [2]. Existing radiotherapy and chemotherapy usually destroy lymphocytes and bone marrow cells, causing serious side effects to the organism. Chitosan nanoparticles have a wide range of 
promising applications in anti-tumor effects, including hepatocellular carcinoma, gastric cancer, colorectal cancer, and lung cancer [5,41]. As indicated in Figure 5, chitosan has anti-proliferative activity against tumor cells, and Liu et al. showed that chitosan induced apoptosis in tumor cells by decreasing Bcl-2 and increasing Caspase-3 expression [42,43] (Figure 5A). Carboxymethyl chitosan (CM-COS) enhances macrophage viability, infiltrates heavily into the tumor microenvironment, produces cytokines such as TNF- $\alpha$ and IL-1, enhances phagocytosis and upregulates NO levels. Notably, CM-COS has inhibitory effects on sarcoma cells in vivo and on BEL-7402 cell growth in vitro but is not significantly toxic to normal liver cells [44,45] (Figure 5B).

In addition, chitosan has an inhibitory effect on tumor cell invasion and metastasis. Matrix metalloenzymes (MMP) are involved in the degradation of extracellular matrix during tumor invasion and metastasis, and MMP-2 can encode an enzyme that degrades type IV collagen [46]. Overexpression of MMP-2 is a prominent feature of gastric cancer, closely associated with gastric cancer metastasis. Chitosan can reduce the expression of cluster of differentiation 147 (CD147) and consequently MMP-2, thus showing a dosedependent inhibition of metastasis of gastric cancer cells [47] (Figure 5C). Angiogenesis within tumor tissues may be related to the upregulation of MMP-9 expression leading to the release of vascular endothelial growth factor (VEGF). The formation of new blood vessels in tumor cells is one of the mechanisms of aggressive tumor metastasis, and VEGF and its receptors are regulatory signals for angiogenesis. Shen et al. found that VEGF expression was higher in lung metastases than in primary tumors [48].COS can inhibit VEGF expression by suppressing the expression of MMP-9, thus inhibiting tumor angiogenesis to suppress tumor invasion and metastasis [49].

A

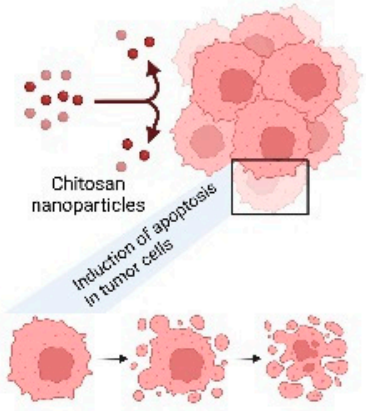

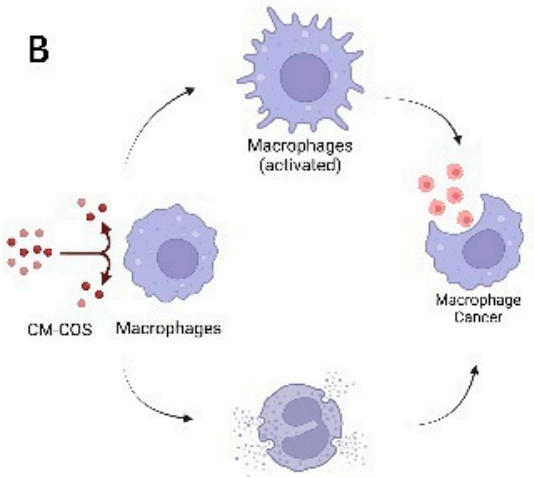

TNF- $a, I L-1$

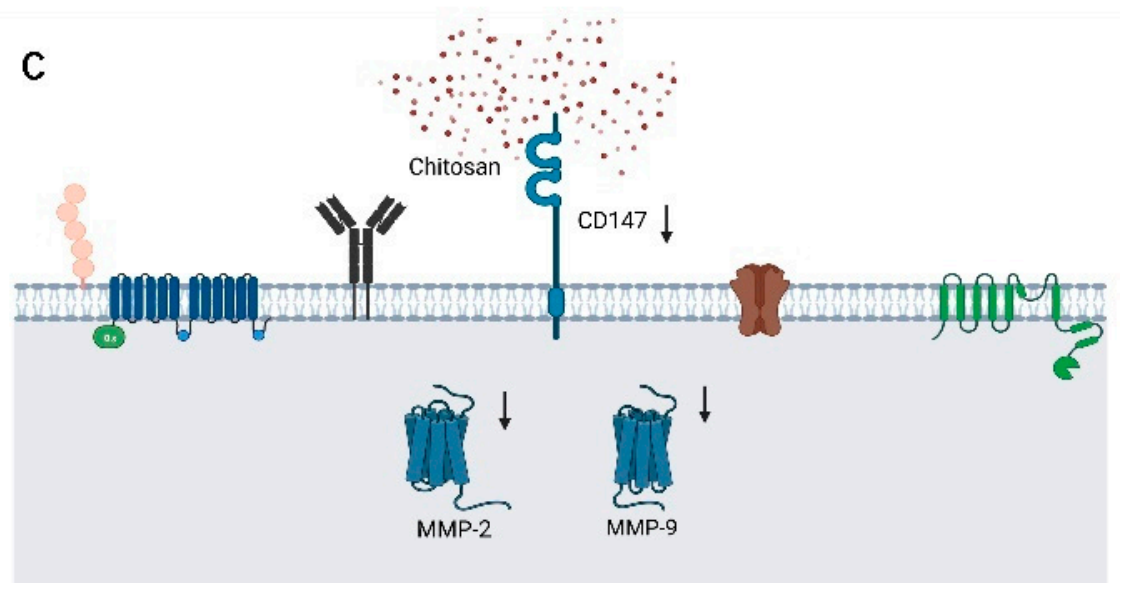

Figure 5. Anti-tumor effects of chitosan and its derivatives. (A) Chitosan induces apoptosis in tumor cells. (B) Carboxymethyl chitosan promotes the secretion of TNF- $\alpha$ and IL-1 cytokines and enhances macrophage phagocytosis. (C) Chitosan inhibits cancer cell metastasis by inhibiting MMP. 


\subsection{Wound Healing}

The ideal trauma dressing should provide a non-toxic, antibacterial, moist, and breathable microenvironment, thus promoting cell proliferation and accelerating wound healing. Positively charged chitosan can promote erythrocyte adhesion, fibrinogen adsorption, accelerate platelet aggregation and activation, and exhibit good hemostatic properties [50]. At the same time, chitosan presents good antibacterial activity due to its large amount of alkaline amino groups, which generally exhibit a cationic charge under acidic conditions, causing lysis and destruction of bacterial cells and protecting the wound surface from microbial infection [51]. Therefore, chitosan has good properties to promote wound healing and is an ideal material for the preparation of wound dressings. In addition, the morphological structure of chitosan nanofibers resembles the extracellular matrix of the skin, thus promoting wound healing [52] (Figure 6A). Zhang et al. prepared a nanocomposite hydrogel using aldehydic sodium alginate (SA), chitosan, and zinc oxide ( $\mathrm{ZnO}$ ) to enhance the antibacterial and coagulation properties [53]. It exhibited significant antibacterial activity against Staphylococcus aureus and Escherichia coli. Shen et al. prepared sulfated chitosan-doped I-sexual collagen hydrogels that enhanced macrophage polarization from M1 to M2. Stimulation of macrophage secretion of IL-4 and TGF- $\beta 1$ enhanced collagen deposition, regenerative epithelialization, and neovascularization [54].

\subsection{Tissue Engineering Materials for Bone and Cartilage}

Tissue engineering is an emerging interdisciplinary discipline that combines material science, engineering mechanics, and biomedicine. The structure and function of damaged tissues and organs are repaired or replaced by cell transplantation combined with bioactive molecules and 3D scaffolds [55]. Mucopolysaccharides in the extracellular matrix play an important role in regulating chondrocyte morphology, function and differentiation. Chitosan is similar to mucopolysaccharides of the extracellular matrix and is used as a scaffolding material for cartilage tissue engineering [56]. The poor mechanical properties of chitosan were improved by synthesizing composites to improve the properties of hydrogels (Figure 6B). Kaviani et al. prepared nanoporous scaffolds using chitosan, collagen, and nanohydroxyapatite by the cryogel method, which reduced the rate of biodegradation and improved mechanical properties and facilitated cell proliferation and adhesion $[3,57]$. Porous scaffolds prepared by using chitosan, gelatin, and silk proteins have better compressive strength and compressive modulus, while incidental chondrocytes can form seed scaffolds and promote rapid regeneration of cartilage tissue [58]. Martino et al. prepared porous composite scaffolds by combining gelatin, chitosan, and polyvinyl alcohol with nano-hydroxyapatite [59]. The experimental results showed that the composite had good compression resistance, bionic structure, and high osteogenic differentiation ability. They effectively promoted the proliferation and adhesion ability of bone marrow mesenchymal stem cells. Therefore, the composite material is expected to be a bone repair and tissue engineering scaffold.

\subsection{Nanocarriers for Drug Delivery}

In recent years, nanomaterials for drug delivery systems have received a lot of attention in the pharmaceutical field. Chitosan is used as a cationic polysaccharide. Chitosan, as a cationic polysaccharide, contains a large number of amino and hydroxyl groups in its molecular chain, which makes it PH sensitive [60]. The design of such PH stimuli-responsive nanohydrogels provides a new idea for drug slow release and delivery. Lactic acid-modified carboxymethyl chitosan methacrylate was cross-linked with ortho-methacrylate monomer to prepare $\mathrm{pH}$-sensitive, tumor-targeting bifunctional nanogels, which improved the growth inhibition and penetration of tumor cells in vitro [61]. This $\mathrm{pH}$-induced drug-release behavior improved its tumor-targeting ability and is expected to be a tumor drug delivery vehicle (Figure 6C).

Cationic chitosan can bind to the negative charge of DNA through ionic bonds to form stable multimers. At the same time, electrostatic interactions between chitosan and genes 
can prevent DNA from degradation by nucleases $[62,63]$. This makes chitosan a promising gene carrier. Delivery of small DNA and short interfering RNA (siRNA) is an important tool to inhibit oncogene expression. siRNA and chitosan form chitosan nanoparticles Chitosan-Based Nanoparticles (CS-NPs). It protects siRNA from enzymatic breakdown and translocates siRNA into target cells $[62,64]$.

It was shown that the longer the blood circulation time of chitosan kinase particles, the more efficient their penetration and retention in the organism. This also suggests that the particle size, particle shape, and surface charge of nanoparticles also affect their blood circulation time and membrane penetration efficiency. Ultimately, to effectively achieve the penetration effect of chitosan, NPs should be able to remain stably in the bloodstream and thus have a better chance to penetrate the tumor vasculature and accumulate in the tumor. Table 2 demonstrates the chitosan-based nanocarriers and their mechanism of action.

Table 2. Chitosan-based nanocarriers and their mechanism.

\begin{tabular}{|c|c|c|c|c|}
\hline Nanocarrier Component & Loaded Drug & Vivo or Vitro & Efficacy Mechanism & Reference \\
\hline Chitosan nanocarrier & Gemcitabine & In vitro & Oral adsorption & [65] \\
\hline $\begin{array}{c}\text { Chitosan/poly(ethylene } \\
\text { glycol) }\end{array}$ & Gemcitabine & $\begin{array}{l}\text { In vitro and } \\
\text { in vivo }\end{array}$ & $\begin{array}{l}\text { Reduce the burden of frequent } \\
\text { dosing and higher toxicity }\end{array}$ & {$[66]$} \\
\hline Chitosan nanoparticle & $\begin{array}{c}\text { Herceptin } \\
\text { (HER2)conjugated } \\
\text { gemcitabine }\end{array}$ & In vitro & $\begin{array}{l}\text { Eventual uptake } \\
\text { and prolonged } \\
\text { intracellular retention }\end{array}$ & [67] \\
\hline O-carboxymethyl chitosan & Curcumin & In vitro & Increase drug solubility & [68] \\
\hline $\begin{array}{l}\text { N-octyl-O-sulfate } \\
\text { chitosan micelles }\end{array}$ & Paclitaxel & In vitro & $\begin{array}{c}\text { Solubilization of } \\
\text { hydrophobic drugs }\end{array}$ & [69] \\
\hline $\begin{array}{c}\text { Glycol chitosan-5ßcholanic } \\
\text { acid (HGC) }\end{array}$ & Camptothecin & $\begin{array}{l}\text { In vitro and } \\
\text { in vivo }\end{array}$ & $\begin{array}{l}\text { Increase drug stability, } \\
\text { solubility and retention }\end{array}$ & {$[70]$} \\
\hline $\begin{array}{c}\text { Hydroxyapatite chitosan } \\
\text { nanocomposite }\end{array}$ & Celecoxib & $\begin{array}{l}\text { In vitro and } \\
\text { in vivo }\end{array}$ & Sustained-release patterns & {$[71]$} \\
\hline
\end{tabular}

\subsection{Potential Application of Chitosan in the Fight against COVID-19}

The endemic strain of coronavirus SARS-CoV-2 is the main causative agent of the novel coronavirus pneumonia (COVID-19). Chitosan can combat viral infections by direct antiviral activity and by inducing antiviral immune response mechanisms. Cationic chitosan can kill viruses by interacting with their negative charges through electrostatic interactions to disrupt their protective membranes [72]. N-(2-hydroxypropyl)-3-methylchitosan ammonium chloride has a strong interaction with the viral $S$ protein, thus forming a complex to prevent viral entry into host cells [73]. Chitosan enhances its antiviral immune response by stimulating immune cells, activating alternative pathways of the complement system [74]. Chitosan is phagocytosed by macrophages and promotes the production of reactive oxygen species (ROS). ROS induces IFN synthesis by splenocytes to exert antiviral effects by inhibiting the translation of viral mRNA [75].

SARS-CoV-2 is mainly transmitted through the respiratory tract or droplets. Infected patients produce aerosol particles by breathing, and the particles are too small to settle, which increases the risk of exposure to health care workers [76]. Hathout et al. proposed the use of positively charged polymers such as chitosan to prepare nanofibers with large surface areas and embed them in protective clothing. The electrostatic repulsion between chitosan nanofibers and positively charged SARS-CoV-2 could reduce the viral load around the protective clothing, thus reducing the ability of the virus to spread [77] (Figure 6D). Chitosan nanoparticle aerosols made by Bioavanta can deliver any potentially anti-COVID19 drug to the lungs. The nanoparticles adhere to the airways and the encapsulated active substance is released due to slow degradation, thus ensuring a high local concentration of 
the drug [75]. Therefore, chitosan delivery of drugs via the intranasal mucosal route is a very promising approach against SARS-CoV-2.
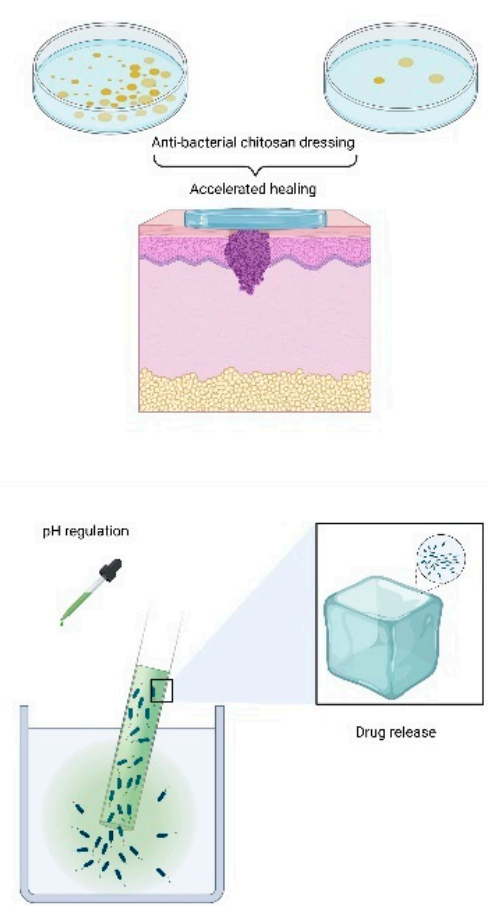

B

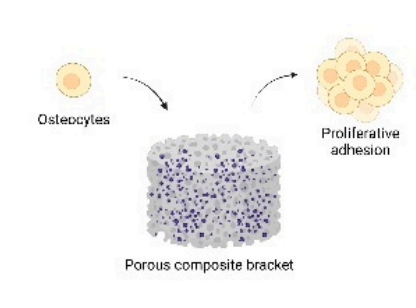

D
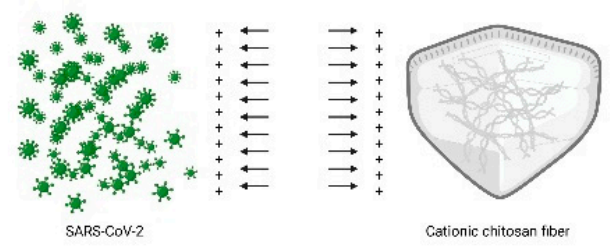

Figure 6. Other biomedical applications of chitosan. (A) Chitosan promotes wound healing. (B) Chitosan as a bone and cartilage tissue engineering repair material. (C) PH-sensitive chitosan drug delivery system. (D) The role of chitosan in the protection against SARS-CoV-2.

\section{Application of Chitosan in the Field of Agriculture}

\subsection{Plant Growth Stimulants}

Fertilizers, pesticides, and large amounts of nutrients are currently the main ways to promote plant growth and development and increase crop yields. However, the continuous use of pesticides is bound to affect the sustainable development of the agricultural economy. In this era of precision agriculture, new environmentally-friendly nano-fertilizers have received great attention. The biodegradability of chitosan can be used to prepare stimulation-controlled drug release systems. Chitosan nanocarriers respond positively to small environmental signals such as ambient temperature and light. It causes changes in structure, solubility and transforms into a gel, which facilitates release. Once the stimulation stops, it returns to the initial structure [78,79]. Stimulation-controlled chitosan nanofertilizers can improve utilization, reduce the dose used, and effectively promote plant growth. Chitosan improves plant tolerance to salinity, high temperature, and drought, and increases photosynthetic efficiency [80]. The hydrophilic nature of chitosan reduces transpiration and promotes water uptake [81,82]. As depicted in Figure 7, chitosan can be used as an additional carbon source in plant synthesis to promote plant growth [83] (Figure 7A). Saharan et al. found that seeds treated with $0.04 \%$ and $0.12 \%$ Cu-chitosan nanoparticles (NPs) had higher germination, seedling length, root length, and root number than the control group [84]. Cu-chitosan NPs can increase protease and $\alpha$-amylase activities to promote the mobilization of protein and starch to promote seedling growth.

\subsection{Chitosan-Based Nanocomplexes (Ch-NCs) for Fungicides}

Chitosan has an inhibitory effect on fungi and bacteria and is a good antimicrobial drug. Cationic Ch-NCs bind to negatively charged microbial cell membranes, leading to changes in cell membrane permeability and leakage of cellular components, causing cell death. Ch-NCs interfere with mRNA and protein synthesis by penetrating into the 
nucleus of microbial cells and binding to DNA. It can also selectively bind to metals, thereby inhibiting the production of microbial toxins. Alternatively, it inhibits oxygen and nutrient uptake by forming a blocking layer on the microbial cell wall [85-88]. It was found that quaternary chitosan has antibacterial activity against Escherichia coli and Staphylococcus aureus, and the antibacterial activity increased with the increasing chain length of alkyl substituents. Ch-NCs can significantly inhibit the growth of Ch-NCs, which is essential for eradicating and preventing bacterial diseases in crops. In addition, Ch-NCs are used in soil conditioners, foliar, and seed treatments. It can inhibit the growth of fungi such as gray mold fungus and Aspergillus flavus at different growth stages, such as mycelial growth, sporulation, and fungal toxin factor production [89]. It was found that injection of spore suspensions of A. gray mold on strawberry fruits, coated with chitosan, and stored at $13{ }^{\circ} \mathrm{C}$ for 14 days significantly slowed down fruit decay (Figure 7B). Therefore, Ch-NCs have a vast application potential as edible antifungal coating material after fruit picking. $\varepsilon$-polylysine and chitosan combination fungicides inhibited tomato gray mold fungus up to $90 \%$ [90]. Cobos et al. found a significant reduction in infection and mortality of fungal pathogens of grapevine trunks after treatment with chitosan in experimental fields [91].

\subsection{Synergistic Effects of Chitosan and Metals}

Metals such as zinc, copper, silver, and nickel are highly compatible with chitosan NPs and are harmless to plant systems. $\mathrm{Cu} 2+, \mathrm{Zn} 2+$, and $\mathrm{Ni2}+$ have fungicidal and disinfectant properties, and when chitosan is combined with metal ions, it enhances the antibacterial activity against A. solanacearum, A. griseus, and A. curvatus. Abd-Elsalam et al. used metal organosols to impregnate chitosan to prepare $\mathrm{Ch}-\mathrm{Zn} \mathrm{NCs}$, the nanomaterials exhibited good antifungal activity and even inhibited the growth of A. solanacearum [92]. $\mathrm{Zn}$ is a cofactor of enzymes involved in protein metabolism and replication of DNA and plays a vital role in the plant immune system. Ch-Zn NCs enhance plant immune response by increasing defense enzymes and antioxidant activity [93]. The formation of reactive oxygen species (ROS) is dependent on light, and after ROS production, they can be rapidly eliminated by antioxidant enzymes. Chitosan can induce plant chloroplasts (or mitochondria) to produce $\mathrm{H} 2 \mathrm{O} 2$, which is involved in the scavenging of reactive oxygen species. Chitosan NPs can also increase the levels of antioxidant enzymes such as peroxidase (POD), catalase (CAT), superoxide dismutase (SOD), and glutathione reductase (GR). Ch-Ag NPs have $\mathrm{POD}$ activity and catalyze the breakdown of $\mathrm{H} 2 \mathrm{O} 2$ into hydroxyl radicals, which facilitates plants against unfavorable environments [94-96].

\subsection{Synergistic Effect of Chitosan and Endophytic Strains}

Endophytic bacteria are microorganisms that colonize the inside of plants at some or all stages of their life history. Endophytic bacteria can produce phytohormones and growth regulators that increase photosynthetic activity and promote plant growth. Drought stress is usually accompanied by ROS formation, which can damage macromolecules and cell membranes. Endophytic bacteria can alter the activity of antioxidant enzymes associated with drought stress to increase drought tolerance in wheat. Endophytic bacteria and chitosan treatment help plants to adapt to drought, scavenge ROS toxic compounds, and reduce cellular damage [97,98]. Endophytic bacteria, such as B. cepacian, Bacillus spp., and Pseudomonas, can break down deaminase precursors and reduce ethylene concentration in plant tissues, while the end products are carbon and nitrogen sources required for plant growth and promote plant growth under abiotic stress conditions [99,100]. Kumar et al. found that treatment when Pseudomonas and chitosan were applied together, sorghum seedlings grew faster. Thus, the combination of chitosan with endophytic bacteria, such as Bacillus cereus, promoted plant growth and control of biological diseases caused by pathogenic bacteria [101]. 
A

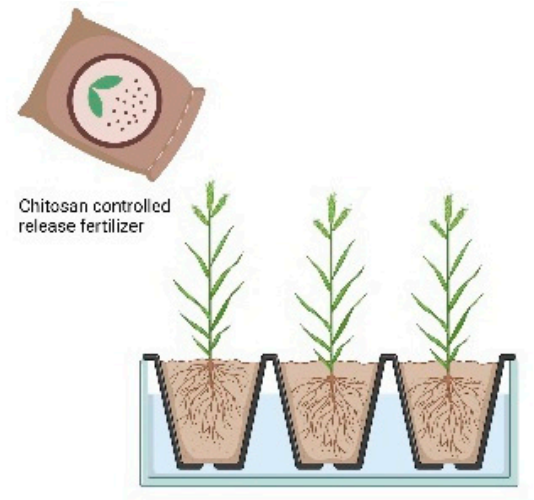

\section{B}

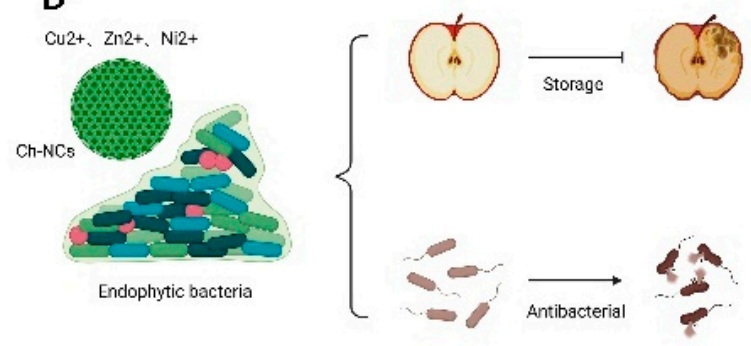

Figure 7. Application of chitosan in the field of agriculture. (A) Chitosan can be used to prepare stimulation-controlled drug release systems. (B) Chitosan synergizes with metal or endophytic bacteria to achieve antiseptic and inhibit harmful bacteria.

\section{Conclusions and Future Prospects}

Chitosan, as a biopolymer obtained by deacetylation, is widely appreciated for its biocompatibility, degradability, antimicrobial properties, and modifiability. Its derivatives can also obtain superior physicochemical properties. This has led to a wider range of applications. The research results of scientists from various countries have demonstrated that chitosan is not only limited to the biomedical field, aiding in solving complex problems nowadays in skin damage, orthopedic endophytes, and even virus protection, but also has applications in the agricultural field.

This paper presents a review of the preparative modification of chitosan and its recent applications in biomedical and agricultural fields. The functional groups and interactions that play an essential role in the modification of chitosan are systematically explained. The functional groups with specific functions are introduced differently due to the modifications (e.g., phosphorylation, sulfhydration, cationization, etc.), thus making them controllable. The wide variety of structural properties and application directions of chitosan derivatives is particularly advantageous to ensure their wide application. Carboxymethyl chitosan exhibits anti-tumor effects by promoting autophagy of tumor cells and enhancing the secretion and phagocytic activity of macrophages. The amino group contained in chitosan has an antimicrobial function and offers the possibility of wound dressing improvement. Complex porous scaffolds made of chitosan have improved mechanical properties and have been progressively applied to bone endosseous plants to promote the crawling and growing of bone cells. In addition, PH-sensitive chitosan can offer the possibility of controlled drug release. Surprisingly, the positive charge carried by cationic chitosan has potential applications in protective gear urgently needed for novel coronary diseases. In agriculture, specific condition-sensitive chitosan can assist in the sustained release of plant nutrient drugs to achieve controlled slow release, plant growth promoters, and fungicidal effects. It is also able to act synergistically with metal ions and plant endophytic bacteria to promote plant growth. In the future, pre-engineered chitosan derivatives with good biocompatibility will have promising applications in biomedical and agricultural fields. 
Author Contributions: Investigation, M.Z. and F.Z.; writing-original draft preparation, M.Z.; visualization, C.L. and H.A.; formal analysis, T.W.; writing-review and editing, P.Z.; supervision, P.Z. All authors have read and agreed to the published version of the manuscript.

Funding: This work was supported by the Beijing Natural Science Foundation, No. 7212121; a grant from National Center for Trauma Medicine, Beijing, China, No. BMU2020XY005-01; the National Natural Science Foundation of China, No. 31771322; Funds of Severe Trauma Standardized Treatment, No. SZSM202011001; (all to P.Z.)

Institutional Review Board Statement: Not applicable.

Informed Consent Statement: Not applicable.

Data Availability Statement: The data presented in this study are available on request from the corresponding author.

Acknowledgments: We are grateful for the assistance of biorender (BioRender.com) in the construction of some of the illustrations.

Conflicts of Interest: The authors declare no conflict of interest.

\section{References}

1. Varlamov, V.; Mysyakina, I. Chitosan in biology, microbiology, medicine, and agriculture. Microbiology 2018, 87, 712-715. [CrossRef]

2. Bandara, S.; Du, H.; Carson, L.; Bradford, D.; Kommalapati, R. Agricultural and biomedical applications of chitosan-based nanomaterials. Nanomaterials 2020, 10, 1903. [CrossRef] [PubMed]

3. Khan, A.; Alamry, K.A. Recent advances of emerging green chitosan-based biomaterials with potential biomedical applications: A review. Carbohydr. Res. 2021, 506, 108368. [CrossRef] [PubMed]

4. Xing, K.; Zhu, X.; Peng, X.; Qin, S. Chitosan antimicrobial and eliciting properties for pest control in agriculture: A review. Agron. Sustain. Dev. 2015, 35, 569-588. [CrossRef]

5. Elkeiy, M.M.; Khamis, A.A.; El-Gamal, M.M.; Gazia, M.M.A.; Zalat, Z.A.; El-Magd, M.A. Chitosan nanoparticles from Artemia salina inhibit progression of hepatocellular carcinoma in vitro and in vivo. Environ. Sci. Pollut. Res. 2020, 27, 19016-19028 [CrossRef] [PubMed]

6. Islam, S.; Bhuiyan, M.R.; Islam, M. Chitin and chitosan: Structure, properties and applications in biomedical engineering. J. Polym. Environ. 2017, 25, 854-866. [CrossRef]

7. Aranaz, I.; Harris, R.; Navarro-García, F.; Heras, A.; Acosta, N. Chitosan based films as supports for dual antimicrobial release. Carbohydr. Polym. 2016, 146, 402-410. [CrossRef]

8. Aranaz, I.; Mengíbar, M.; Harris, R.; Miralles, B.; Acosta, N.; Calderón, L.; Sánchez, Á.; Heras, Á. Role of physicochemical properties of chitin and chitosan on their functionality. Curr. Chem. Biol. 2014, 8, 27-42. [CrossRef]

9. Vllasaliu, D.; Casettari, L.; Fowler, R.; Exposito-Harris, R.; Garnett, M.; Illum, L.; Stolnik, S. Absorption-promoting effects of chitosan in airway and intestinal cell lines: A comparative study. Int. J. Pharm. 2012, 430, 151-160. [CrossRef]

10. Rosenthal, R.; Günzel, D.; Finger, C.; Krug, S.M.; Richter, J.F.; Schulzke, J.-D.; Fromm, M.; Amasheh, S. The effect of chitosan on transcellular and paracellular mechanisms in the intestinal epithelial barrier. Biomaterials 2012, 33, 2791-2800. [CrossRef]

11. Qin, Y.; Li, P.; Guo, Z. Cationic chitosan derivatives as potential antifungals: A review of structural optimization and applications. Carbohydr. Polym. 2020, 236, 116002. [CrossRef] [PubMed]

12. Sahariah, P.; Masson, M. Antimicrobial chitosan and chitosan derivatives: A review of the structure-activity relationship. Biomacromolecules 2017, 18, 3846-3868. [CrossRef]

13. Luo, Q.; Han, Q.; Wang, Y.; Zhang, H.; Fei, Z.; Wang, Y. The thiolated chitosan: Synthesis, gelling and antibacterial capability. Int. J. Biol. Macromol. 2019, 139, 521-530. [CrossRef] [PubMed]

14. Bombaldi de Souza, R.F.; de Souza, F.C.B.; Thorpe, A.; Mantovani, D.; Popat, K.C.; Moraes, Â.M. Phosphorylation of chitosan to improve osteoinduction of chitosan/xanthan-based scaffolds for periosteal tissue engineering. Int. J. Biol. Macromol. 2020, 143, 619-632. [CrossRef] [PubMed]

15. Patel, S.; Srivastava, S.; Singh, M.R.; Singh, D. Preparation and optimization of chitosan-gelatin films for sustained delivery of lupeol for wound healing. Int. J. Biol. Macromol. 2018, 107, 1888-1897. [CrossRef]

16. Negm, N.A.; Hefni, H.H.H.; Abd-Elaal, A.A.A.; Badr, E.A.; Abou Kana, M.T.H. Advancement on modification of chitosan biopolymer and its potential applications. Int. J. Biol. Macromol. 2020, 152, 681-702. [CrossRef]

17. Tan, W.; Li, Q.; Dong, F.; Chen, Q.; Guo, Z. Preparation and Characterization of Novel Cationic Chitosan Derivatives Bearing Quaternary Ammonium and Phosphonium Salts and Assessment of Their Antifungal Properties. Molecules 2017, $22,1438$. [CrossRef]

18. Dimassi, S.; Tabary, N.; Chai, F.; Blanchemain, N.; Martel, B. Sulfonated and sulfated chitosan derivatives for biomedical applications: A review. Carbohydr. Polym. 2018, 202, 382-396. [CrossRef] 
19. Liu, L.; Miao, Y.; Shi, X.; Gao, H.; Wang, Y. Phosphorylated Chitosan Hydrogels Inducing Osteogenic Differentiation of Osteoblasts via JNK and p38 Signaling Pathways. ACS Biomater. Sci. Eng. 2020, 6, 1500-1509. [CrossRef]

20. Wei, J.; Xue, W.; Yu, X.; Qiu, X.; Liu, Z. pH Sensitive phosphorylated chitosan hydrogel as vaccine delivery system for intramuscular immunization. J. Biomater. Appl. 2017, 31, 1358-1369. [CrossRef]

21. Han, G.; Liu, S.; Pan, Z.; Lin, Y.; Ding, S.; Li, L.; Luo, B.; Jiao, Y.; Zhou, C. Sulfonated chitosan and phosphorylated chitosan coated polylactide membrane by polydopamine-assisting for the growth and osteogenic differentiation of MC3T3-E1s. Carbohydr. Polym. 2020, 229, 115517. [CrossRef] [PubMed]

22. Jayakumar, R.; Selvamurugan, N.; Nair, S.k.V.; Tokura, S.; Tamura, H. Preparative methods of phosphorylated chitin and chitosan-An overview. Int. J. Biol. Macromol. 2008, 43, 221-225. [CrossRef]

23. Ardean, C.; Davidescu, C.M.; Nemeş, N.S.; Negrea, A.; Ciopec, M.; Duteanu, N.; Negrea, P.; Duda-Seiman, D.; Musta, V. Factors influencing the antibacterial activity of chitosan and chitosan modified by functionalization. Int. J. Mol. Sci. 2021, $22,7449$. [CrossRef] [PubMed]

24. Muzzarelli, R.A. Chitosan composites with inorganics, morphogenetic proteins and stem cells, for bone regeneration. Carbohydr. Polym. 2011, 83, 1433-1445. [CrossRef]

25. LogithKumar, R.; KeshavNarayan, A.; Dhivya, S.; Chawla, A.; Saravanan, S.; Selvamurugan, N. A review of chitosan and its derivatives in bone tissue engineering. Carbohydr. Polym. 2016, 151, 172-188. [CrossRef] [PubMed]

26. Bernkop-Schnürch, A.; Hornof, M.; Guggi, D. Thiolated chitosans. Eur. J. Pharm. Biopharm. 2004, 57, 9-17. [CrossRef]

27. Liu, X.; Li, X.; Zhang, R.; Wang, L.; Feng, Q. A novel dual microsphere based on water-soluble thiolated chitosan/mesoporous calcium carbonate for controlled dual drug delivery. Mater. Lett. 2021, 285, 129142. [CrossRef]

28. Mueller, C.; Verroken, A.; Iqbal, J.; Bernkop-Schnuerch, A. Thiolated chitosans: In vitro comparison of mucoadhesive properties. J. Appl. Polym. Sci. 2012, 124, 5046-5055. [CrossRef]

29. Laffleur, F. Evaluation of chemical modified hydrogel formulation for topical suitability. Int. J. Biol. Macromol. 2017, 105, 1310-1314. [CrossRef]

30. Federer, C.; Kurpiers, M.; Bernkop-Schnurch, A. Thiolated chitosans: A multi-talented class of polymers for various applications Biomacromolecules 2020, 22, 24-56. [CrossRef]

31. Zhang, Y.; Zhou, S.; Deng, F.; Chen, X.; Wang, X.; Wang, Y.; Zhang, H.; Dai, W.; He, B.; Zhang, Q. The function and mechanism of preactivated thiomers in triggering epithelial tight junctions opening. Eur. J. Pharm. Biopharm. 2018, 133, 188-199. [CrossRef] [PubMed]

32. Mirani, Z.A.; Fatima, A.; Urooj, S.; Aziz, M.; Khan, M.N.; Abbas, T. Relationship of cell surface hydrophobicity with biofilm formation and growth rate: A study on Pseudomonas aeruginosa, Staphylococcus aureus, and Escherichia coli. Iran. J. Basic Med. Sci. 2018, 21, 760. [PubMed]

33. Xu, L.Q.; Pranantyo, D.; Neoh, K.-G.; Kang, E.-T.; Fu, G.D. Thiol reactive maleimido-containing tannic acid for the bioinspired surface anchoring and post-functionalization of antifouling coatings. ACS Sustain. Chem. Eng. 2016, 4, 4264-4272. [CrossRef]

34. Mi, Y.; Tan, W.; Zhang, J.; Wei, L.; Chen, Y.; Li, Q.; Dong, F.; Guo, Z. Synthesis, characterization, and antifungal property of hydroxypropyltrimethyl ammonium chitosan halogenated acetates. Mar. Drugs 2018, 16, 315. [CrossRef] [PubMed]

35. Wei, L.; Tan, W.; Wang, G.; Li, Q.; Dong, F.; Guo, Z. The antioxidant and antifungal activity of chitosan derivatives bearing Schiff bases and quaternary ammonium salts. Carbohydr. Polym. 2019, 226, 115256. [CrossRef] [PubMed]

36. Liu, W.; Qin, Y.; Liu, S.; Xing, R.; Yu, H.; Chen, X.; Li, K.; Li, P. Synthesis, characterization and antifungal efficacy of chitosan derivatives with triple quaternary ammonium groups. Int. J. Biol. Macromol. 2018, 114, 942-949. [CrossRef]

37. Shagdarova, B.; Lunkov, A.; Il'ina, A.; Varlamov, V. Investigation of the properties of N-[(2-hydroxy-3-trimethylammonium) propyl] chloride chitosan derivatives. Int. J. Biol. Macromol. 2019, 124, 994-1001. [CrossRef]

38. De Oliveira Pedro, R.; Schmitt, C.C.; Neumann, M.G. Syntheses and characterization of amphiphilic quaternary ammonium chitosan derivatives. Carbohydr. Polym. 2016, 147, 97-103. [CrossRef]

39. Tan, W.; Zhang, J.; Mi, Y.; Dong, F.; Li, Q.; Guo, Z. Synthesis, characterization, and evaluation of antifungal and antioxidant properties of cationic chitosan derivative via azide-alkyne click reaction. Int. J. Biol. Macromol. 2018, 120, 318-324. [CrossRef]

40. Song, H.; Wu, H.; Li, S.; Tian, H.; Li, Y.; Wang, J. Homogeneous synthesis of cationic chitosan via new avenue. Molecules 2018, 23, 1921. [CrossRef]

41. Yuan, X.; Zheng, J.; Jiao, S.; Cheng, G.; Feng, C.; Du, Y.; Liu, H. A review on the preparation of chitosan oligosaccharides and application to human health, animal husbandry and agricultural production. Carbohydr. Polym. 2019, 220, 60-70. [CrossRef] [PubMed]

42. Liu, L.; Xin, Y.; Liu, J.; Zhang, E.; Li, W. Inhibitory effect of chitosan oligosaccharide on human hepatoma cells in vitro. Afr. J. Tradit. Complementary Altern. Med. 2017, 14, 272-277. [CrossRef] [PubMed]

43. Ngo, D.H.; Ngo, D.N.; Kim, S.-K.; Vo, T.S. Antiproliferative effect of aminoethyl-chitooligosaccharide on human lung A549 cancer cells. Biomolecules 2019, 9, 195. [CrossRef] [PubMed]

44. Jiang, Z.; Wang, S.; Hou, J.; Chi, J.; Wang, S.; Shao, K.; Liu, W.; Sun, R.; Han, B. Effects of carboxymethyl chitosan oligosaccharide on regulating immunologic function and inhibiting tumor growth. Carbohydr. Polym. 2020, 250, 116994. [CrossRef]

45. Zhai, X.; Li, C.; Ren, D.; Wang, J.; Ma, C.; Abd El-Aty, A. The impact of chitooligosaccharides and their derivatives on the in vitro and in vivo anti-tumor activity: A comprehensive review. Carbohydr. Polym. 2021, 266, 118132. [CrossRef] [PubMed] 
46. Muanprasat, C.; Chatsudthipong, V. Chitosan oligosaccharide: Biological activities and potential therapeutic applications. Pharmacol. Ther. 2017, 170, 80-97. [CrossRef] [PubMed]

47. Luo, Z.; Dong, X.; Ke, Q.; Duan, Q.; Shen, L. Downregulation of CD147 by chitooligosaccharide inhibits MMP-2 expression and suppresses the metastatic potential of human gastric cancer. Oncol. Lett. 2014, 8, 361-366. [CrossRef] [PubMed]

48. Shen, K.-T.; Chen, M.-H.; Chan, H.-Y.; Jeng, J.-H.; Wang, Y.-J. Inhibitory effects of chitooligosaccharides on tumor growth and metastasis. Food Chem. Toxicol. 2009, 47, 1864-1871. [CrossRef]

49. Xu, W.; Jiang, C.; Kong, X.; Liang, Y.; Rong, M.; Liu, W. Chitooligosaccharides and N-acetyl-D-glucosamine stimulate peripheral blood mononuclear cell-mediated anti-tumor immune responses. Mol. Med. Rep. 2012, 6, 385-390. [CrossRef]

50. He, Q.; Gong, K.; Ao, Q.; Ma, T.; Yan, Y.; Gong, Y.; Zhang, X. Positive charge of chitosan retards blood coagulation on chitosan films. J. Biomater. Appl. 2013, 27, 1032-1045. [CrossRef]

51. Wang, C.-H.; Cherng, J.-H.; Liu, C.-C.; Fang, T.-J.; Hong, Z.-J.; Chang, S.-J.; Fan, G.-Y.; Hsu, S.-D. Procoagulant and Antimicrobial Effects of Chitosan in Wound Healing. Int. J. Mol. Sci. 2021, 22, 7067. [CrossRef] [PubMed]

52. Sarhan, W.A.; Azzazy, H.M.; El-Sherbiny, I.M. Honey/chitosan nanofiber wound dressing enriched with Allium sativum and Cleome droserifolia: Enhanced antimicrobial and wound healing activity. ACS Appl. Mater. Interfaces 2016, 8, 6379-6390. [CrossRef] [PubMed]

53. Zhang, M.; Qiao, X.; Han, W.; Jiang, T.; Liu, F.; Zhao, X. Alginate-chitosan oligosaccharide-ZnO composite hydrogel for accelerating wound healing. Carbohydr. Polym. 2021, 266, 118100. [CrossRef] [PubMed]

54. Shen, T.; Dai, K.; Yu, Y.; Wang, J.; Liu, C. Sulfated chitosan rescues dysfunctional macrophages and accelerates wound healing in diabetic mice. Acta Biomater. 2020, 117, 192-203. [CrossRef]

55. Venkatesan, J.; Kim, S.-K. Chitosan composites for bone tissue engineering-An overview. Mar. Drugs 2010, 8, 2252-2266. [CrossRef]

56. Di Martino, A.; Sittinger, M.; Risbud, M.V. Chitosan: A versatile biopolymer for orthopaedic tissue-engineering. Biomaterials 2005, 26, 5983-5990. [CrossRef]

57. Kaviani, A.; Zebarjad, S.M.; Javadpour, S.; Ayatollahi, M.; Bazargan-Lari, R. Fabrication and characterization of low-cost freezegelated chitosan/collagen/hydroxyapatite hydrogel nanocomposite scaffold. Int. J. Polym. Anal. Charact. 2019, 24, 191-203. [CrossRef]

58. Haghighi, P.; Shamloo, A. Fabrication of a novel 3D scaffold for cartilage tissue repair: In-vitro and in-vivo study. Mater. Sci. Eng. C 2021, 128, 112285. [CrossRef]

59. Ma, P.; Wu, W.; Wei, Y.; Ren, L.; Lin, S.; Wu, J. Biomimetic gelatin/chitosan/polyvinyl alcohol/nano-hydroxyapatite scaffolds for bone tissue engineering. Mater. Des. 2021, 207, 109865. [CrossRef]

60. Xing, L.; Fan, Y.-T.; Shen, L.-J.; Yang, C.-X.; Liu, X.-Y.; Ma, Y.-N.; Qi, L.-Y.; Cho, K.-H.; Cho, C.-S.; Jiang, H.-L. pH-sensitive and specific ligand-conjugated chitosan nanogels for efficient drug delivery. Int. J. Biol. Macromol. 2019, 141, 85-97. [CrossRef]

61. Zha, Q.; Wang, X.; Cheng, X.; Fu, S.; Yang, G.; Yao, W.; Tang, R. Acid-degradable carboxymethyl chitosan nanogels via an ortho ester linkage mediated improved penetration and growth inhibition of 3-D tumor spheroids in vitro. Mater. Sci. Eng. C 2017, 78, 246-257. [CrossRef] [PubMed]

62. Cao, Y.; Tan, Y.F.; Wong, Y.S.; Liew, M.W.J.; Venkatraman, S. Recent advances in chitosan-based carriers for gene delivery. Mar. Drugs 2019, 17, 381. [CrossRef] [PubMed]

63. Iacob, A.T.; Lupascu, F.G.; Apotrosoaei, M.; Vasincu, I.M.; Tauser, R.G.; Lupascu, D.; Giusca, S.E.; Caruntu, I.-D.; Profire, L. Recent Biomedical Approaches for Chitosan Based Materials as Drug Delivery Nanocarriers. Pharmaceutics 2021, 13, 587. [CrossRef] [PubMed]

64. Cristofolini, T.; Dalmina, M.; Sierra, J.A.; Silva, A.H.; Pasa, A.A.; Pittella, F.; Creczynski-Pasa, T.B. Multifunctional hybrid nanoparticles as magnetic delivery systems for siRNA targeting the HER2 gene in breast cancer cells. Mater. Sci. Eng. C 2020, 109, 110555. [CrossRef]

65. Derakhshandeh, K.; Fathi, S. Role of chitosan nanoparticles in the oral absorption of Gemcitabine. Int. J. Pharm. 2012, 437, 172-177. [CrossRef]

66. Garg, N.K.; Dwivedi, P.; Campbell, C.; Tyagi, R.K. Site specific/targeted delivery of gemcitabine through anisamide anchored chitosan/poly ethylene glycol nanoparticles: An improved understanding of lung cancer therapeutic intervention. Eur. J. Pharm. Sci. 2012, 47, 1006-1014. [CrossRef]

67. Arya, G.; Vandana, M.; Acharya, S.; Sahoo, S.K. Enhanced antiproliferative activity of Herceptin (HER2)-conjugated gemcitabineloaded chitosan nanoparticle in pancreatic cancer therapy. Nanomedicine 2011, 7, 859-870. [CrossRef]

68. Anitha, A.; Maya, S.; Deepa, N.; Chennazhi, K.; Nair, S.; Tamura, H.; Jayakumar, R. Efficient water soluble O-carboxymethyl chitosan nanocarrier for the delivery of curcumin to cancer cells. Carbohydr. Polym. 2011, 83, 452-461. [CrossRef]

69. Zhang, C.; Qu, G.; Sun, Y.; Yang, T.; Yao, Z.; Shen, W.; Shen, Z.; Ding, Q.; Zhou, H.; Ping, Q. Biological evaluation of N-octyl-Osulfate chitosan as a new nano-carrier of intravenous drugs. Eur. J. Pharm. Sci. 2008, 33, 415-423. [CrossRef]

70. Min, K.H.; Park, K.; Kim, Y.S.; Bae, S.M.; Lee, S.; Jo, H.G.; Park, R.W.; Kim, I.S.; Jeong, S.Y.; Kim, K.; et al. Hydrophobically modified glycol chitosan nanoparticles-encapsulated camptothecin enhance the drug stability and tumor targeting in cancer therapy. J. Control. Release 2008, 127, 208-218. [CrossRef] 
71. Venkatesan, P.; Puvvada, N.; Dash, R.; Prashanth Kumar, B.N.; Sarkar, D.; Azab, B.; Pathak, A.; Kundu, S.C.; Fisher, P.B.; Mandal, $\mathrm{M}$. The potential of celecoxib-loaded hydroxyapatite-chitosan nanocomposite for the treatment of colon cancer. Biomaterials 2011, 32, 3794-3806. [CrossRef] [PubMed]

72. Raafat, D.; Sahl, H.G. Chitosan and its antimicrobial potential-a critical literature survey. Microb. Biotechnol. 2009,2 , 186-201. [CrossRef] [PubMed]

73. Milewska, A.; Chi, Y.; Szczepanski, A.; Barreto-Duran, E.; Dabrowska, A.; Botwina, P.; Obloza, M.; Liu, K.; Liu, D.; Guo, X. HTCC as a Polymeric Inhibitor of SARS-CoV-2 and MERS-CoV. J. Virol. 2020, 95, e01622-20. [CrossRef] [PubMed]

74. Jaber, N.; Al-Remawi, M.; Al-Akayleh, F.; Al-Muhtaseb, N.; Al-Adham, I.S.; Collier, P.J. A review of the antiviral activity of Chitosan, including patented applications and its potential use against COVID-19. J. Appl. Microbiol. 2021, 132, 41-58. [CrossRef]

75. Safarzadeh, M.; Sadeghi, S.; Azizi, M.; Rastegari-Pouyani, M.; Pouriran, R.; Hoseini, M.H.M. Chitin and chitosan as tools to combat COVID-19: A triple approach. Int. J. Biol. Macromol. 2021, 183, 235-244. [CrossRef] [PubMed]

76. Meselson, M. Droplets and aerosols in the transmission of SARS-CoV-2. N. Engl. J. Med. 2020, 382, 2063. [CrossRef]

77. Hathout, R.M.; Kassem, D.H. Positively charged electroceutical spun chitosan nanofibers can protect health care providers from COVID-19 infection: An opinion. Front. Bioeng. Biotechnol. 2020, 8, 8. [CrossRef]

78. Neri-Badang, M.C.; Chakraborty, S. Carbohydrate polymers as controlled release devices for pesticides. J. Carbohydr. Chem. 2019, 38, 67-85. [CrossRef]

79. Yu, J.; Wang, D.; Geetha, N.; Khawar, K.M.; Jogaiah, S.; Mujtaba, M. Current trends and challenges in the synthesis and applications of chitosan-based nanocomposites for plants: A review. Carbohydr. Polym. 2021, 261, 117904. [CrossRef]

80. Pichyangkura, R.; Chadchawan, S. Biostimulant activity of chitosan in horticulture. Sci. Hortic. 2015, 196, 49-65. [CrossRef]

81. Shahrajabian, M.H.; Chaski, C.; Polyzos, N.; Tzortzakis, N.; Petropoulos, S.A. Sustainable Agriculture Systems in Vegetable Production Using Chitin and Chitosan as Plant Biostimulants. Biomolecules 2021, 11, 819. [CrossRef] [PubMed]

82. Bittelli, M.; Flury, M.; Campbell, G.S.; Nichols, E.J. Reduction of transpiration through foliar application of chitosan. Agric. For. Meteorol. 2001, 107, 167-175. [CrossRef]

83. Pirbalouti, A.G.; Malekpoor, F.; Salimi, A.; Golparvar, A. Exogenous application of chitosan on biochemical and physiological characteristics, phenolic content and antioxidant activity of two species of basil (Ocimum ciliatum and Ocimum basilicum) under reduced irrigation. Sci. Hortic. 2017, 217, 114-122. [CrossRef]

84. Saharan, V.; Kumaraswamy, R.; Choudhary, R.C.; Kumari, S.; Pal, A.; Raliya, R.; Biswas, P. Cu-chitosan nanoparticle mediated sustainable approach to enhance seedling growth in maize by mobilizing reserved food. J. Agric. Food Chem. 2016, 64, 6148-6155. [CrossRef] [PubMed]

85. Wang, X.; Du, Y.; Fan, L.; Liu, H.; Hu, Y. Chitosan-metal complexes as antimicrobial agent: Synthesis, characterization and structure-activity study. Polym. Bull. 2005, 55, 105-113. [CrossRef]

86. Li, Z.; Yang, F.; Yang, R. Synthesis and characterization of chitosan derivatives with dual-antibacterial functional groups. Int. J. Biol. Macromol. 2015, 75, 378-387. [CrossRef] [PubMed]

87. Yuan, G.; Lv, H.; Tang, W.; Zhang, X.; Sun, H. Effect of chitosan coating combined with pomegranate peel extract on the quality of Pacific white shrimp during iced storage. Food Control. 2016, 59, 818-823. [CrossRef]

88. Severino, R.; Ferrari, G.; Vu, K.D.; Donsì, F.; Salmieri, S.; Lacroix, M. Antimicrobial effects of modified chitosan based coating containing nanoemulsion of essential oils, modified atmosphere packaging and gamma irradiation against Escherichia coli O157: H7 and Salmonella Typhimurium on green beans. Food Control. 2015, 50, 215-222. [CrossRef]

89. Rabea, E.I.; Badawy, M.E.-T.; Stevens, C.V.; Smagghe, G.; Steurbaut, W. Chitosan as antimicrobial agent: Applications and mode of action. Biomacromolecules 2003, 4, 1457-1465. [CrossRef]

90. Sun, G.; Yang, Q.; Zhang, A.; Guo, J.; Liu, X.; Wang, Y.; Ma, Q. Synergistic effect of the combined bio-fungicides $\varepsilon$-poly-l-lysine and chitooligosaccharide in controlling grey mould (Botrytis cinerea) in tomatoes. Int. J. Food Microbiol. 2018, 276, 46-53. [CrossRef]

91. Cobos, R.; Mateos, R.M.; Álvarez-Pérez, J.M.; Olego, M.A.; Sevillano, S.; González-García, S.; Garzón-Jimeno, E.; Coque, J.J.R. Effectiveness of natural antifungal compounds in controlling infection by grapevine trunk disease pathogens through pruning wounds. Appl. Environ. Microbiol. 2015, 81, 6474-6483. [CrossRef] [PubMed]

92. Abd-Elsalam, K.A.; Vasil'kov, A.Y.; Said-Galiev, E.E.; Rubina, M.S.; Khokhlov, A.R.; Naumkin, A.V.; Shtykova, E.V.; Alghuthaymi, M.A. Bimetallic blends and chitosan nanocomposites: Novel antifungal agents against cotton seedling damping-off. Eur. J. Plant Pathol. 2018, 151, 57-72. [CrossRef]

93. Choudhary, R.C.; Kumaraswamy, R.; Kumari, S.; Sharma, S.; Pal, A.; Raliya, R.; Biswas, P.; Saharan, V. Zinc encapsulated chitosan nanoparticle to promote maize crop yield. Int. J. Biol. Macromol. 2019, 127, 126-135. [CrossRef] [PubMed]

94. Agrawal, G.K.; Rakwal, R.; Tamogami, S.; Yonekura, M.; Kubo, A.; Saji, H. Chitosan activates defense/stress response (s) in the leaves of Oryza sativa seedlings. Plant Physiol. Biochem. 2002, 40, 1061-1069. [CrossRef]

95. Sen, S.K.; Chouhan, D.; Das, D.; Ghosh, R.; Mandal, P. Improvisation of salinity stress response in mung bean through solid matrix priming with normal and nano-sized chitosan. Int. J. Biol. Macromol. 2020, 145, 108-123. [CrossRef]

96. Chouhan, D.; Mandal, P. Applications of chitosan and chitosan based metallic nanoparticles in agrosciences-A review. Int. J. Biol. Macromol. 2021, 166, 1554-1569. [CrossRef]

97. Naveed, M.; Hussain, M.B.; Zahir, Z.A.; Mitter, B.; Sessitsch, A. Drought stress amelioration in wheat through inoculation with Burkholderia phytofirmans strain PsJN. Plant Growth Regul. 2014, 73, 121-131. [CrossRef] 
98. Amine, R.; Tarek, C.; Hassane, E.; Noureddine, E.H.; Khadija, O. Chemical Proprieties of Biopolymers (Chitin/Chitosan) and Their Synergic Effects with Endophytic Bacillus Species: Unlimited Applications in Agriculture. Molecules 2021, $26,1117$.

99. Glick, B.R.; Todorovic, B.; Czarny, J.; Cheng, Z.; Duan, J.; McConkey, B. Promotion of plant growth by bacterial ACC deaminase. Crit. Rev. Plant Sci. 2007, 26, 227-242. [CrossRef]

100. Nadeem, S.M.; Zahir, Z.A.; Naveed, M.; Ashraf, M. Microbial ACC-deaminase: Prospects and applications for inducing salt tolerance in plants. Crit. Rev. Plant Sci. 2010, 29, 360-393. [CrossRef]

101. Kumar, G.P.; Desai, S.; Moerschbacher, B.M.; Eddine-El Gueddari, N. Seed treatment with chitosan synergizes plant growth promoting ability of Pseudomonas aeruginosa-P17 in sorghum (Sorhum bicolor L.). bioRxiv 2019, 10, 601328. 